\title{
A new species of Gnomidolon Thomson, 1864 and taxonomic and geographical notes on Hexoplonini (Coleoptera, Cerambycidae) from Colombia
}

\author{
Kimberly García \\ 1 Universidad del Atlántico (UA), Facultad de Ciencias Básicas, Programa de Biología, Semillero de investigación Artrópodos Neoptera del Caribe \\ Colombiano. Puerto Colombia, Atlántico, Colombia. ORCID: http://orcid.org/0000-0002-3631-180X. E-mail: kimberly.pg@gmail.com
}

\begin{abstract}
A new species of Gnomidolon from Colombia is described and illustrated: Gnomidolon franciscoi sp. nov.; and the previous key for the genus is modified to include the new species. The male of Gnomidolon hamatum Linsley, 1935 is described and illustrated for the first time. Additionally, a chromatic variation in some species of Hexoplonini from Colombia is reported and the geographical distribution of four species is expanded.
\end{abstract}

Key-Words. Atlántico; Bolívar; Glyptoscapus; Taxonomy; Tropical dry forest.

\section{INTRODUCTION}

The tribe Hexoplonini (Martins, 2006) is currently composed of 22 genera and 156 species (Tavakilian \& Chevillotte, 2018), with geographical distribution restricted to Central (including the Caribbean) and South America (Bezark, 2019). In Colombia, the tribe is currently represented by four genera and 14 species (Botero, 2018).

According toTavakilian \&Chevillotte (2018), the most diverse genus in Hexoplonini is Gnomidolon Thomson, 1864, currently composed of 67 species, which are mainly distributed in South America; for Colombia, there are nine species reported (Botero, 2018). The genus Gnomidolon was proposed by Thomson (1864) to bring together species initially described in Ibidion Audinet-Serville, 1834 (currently Neoibidion Monné, 2012) with short spine at outer apex of metafemora (Martins, 2006).

The genus Glyptoscapus Aurivillius, 1899 differs from other genera of Hexoplonini in having a cicatrix at apex of scape; the third antennomere elongated; the prothorax smooth and without distinct constriction, and the elytra not distinctly depressed on central area (Martins, 2006; Nascimento \& Santos-Silva, 2018). Currently, there are four Glyptoscapus species distributed in South America, and two species from Colombia (Botero, 2018)

In this work, a new species of Gnomidolon is described; the male of $G$. hamatum is described and illustrated, some chromatic variations are re- ported for Gnomidolon bellus Martins \& Galileo, 2002 and Glyptoscapus pallidulus (White, 1855) and the geographical distribution of four species is expanded. Additionally, the key proposed by Martins (2006) for Gnomidolon is modified to include the new species described herein.

\section{MATERIAL AND METHODS}

The material examined was obtained in the Caribbean region of Colombia, in the Reserva La Flecha (RLF), Bolívar and the Reserva Campesina la Montaña (RCM), Atlántico (fragments of tropical dry forest). These locations were sampled from February to June 2018 by using a UV light trap, white light trap, manual capture and beating sheet. The sampling was supplemented by visits to entomological collections.

The material currently resides in the following institutions, which are subsequently referred to by their acronyms:

CASC California Academy of Sciences, San Francisco, California, USA (Chris Grinter);

IAVH Instituto de Investigaciones de Recursos Biológicos "Alexander von Humboldt", Villa de Leyva, Colombia (Jhon Cesar Neita):

MPUJ Pontificia Universidad Javeriana, Bogotá, Colombia (Igor Dimitri Forero, Giovanny Fagua); 
MZSP Museu de Zoologia, Universidade de São Paulo, São Paulo, Brazil (Sônia Casari, Antonio Santos-Silva);

UARC Universidad del Atlántico, Puerto Colombia, Colombia (Neis José Martínez).

Photographs were taken with a Canon EOS Rebel T3i DSLR camera, Canon MP-E 65 mm f/2.8 1-5X macro lens, controlled by Zerene Stacker focus stacking software. Measurements were taken in " $\mathrm{mm}$ " using the software Leica Application Suite (LAS 4.0) and the Leica M125 stereomicroscope, also used in the study of the specimens. References and geographical distributions were ascertained in Martínez (2000), and Monné (2018) and Tavakilian \& Chevillotte (2018) catalogs.

\section{RESULTS}

\section{Cerambycinae Latreille, 1802 \\ Hexoplonini Martins, 2006 \\ Glyptoscapus Aurivillius, 1899}

\section{Glyptoscapus pallidulus (White, 1855) (Figs. 1A-1B)}

Material examined: COLOMBIA, Bolívar: San Jacinto (Reserva La Flecha, 324 m, 0951'12.4"N, 75¹0'41.4"W, tropical dry forest), 2 males, 15.IV.2018, García, K. col., Beating sheet (UARC).

Remarks: Glyptoscapus pallidulus was initially described by White (1855) in the genus Ibidion, without mention the presence of a cicatrix in the apex of the scape (Nascimento \& Santos-Silva, 2018), a characteristic only present in two genera of Hexoplonini (Glyptoscapus and Glyptoceridion Martins, 1959). Thirteen years later, Lacordaire (1868) placed this species in Gnomidolon and then, Martins (1967) transferred it to Glyptoscapus, where is currently allocated. Recently, Nascimento \& Santos-Silva (2018) synonymized Glyptoscapus vanettii (Martins, 1959) and G. cicatricosus (Aurivillius, 1899) with G. pallidulus, as they identified it is an extremely variable species. According to Nascimento \& Santos-Silva (2018) the variable characteristics are: "the general coloration, color of the head and pronotum, length, ratio and shape of spines of meso- and metafemora, number of rows of the elytra setae, etc."

Specimens of G. pallidulus from Colombia were examined and compared with several specimens from the MZSP, and other chromatic variations in this species were noticed, complementing the variability currently known. The Colombian specimens (Fig. 1A) have darker legs, femora brown (mainly meso- and metafemora) and tibiae dark brown (mainly meso- and metatibiae); also, antennomere III is dark brown at anterior half, darker than other specimens (Fig. 1B). Currently, the species is recorded from the department of Magdalena in Colombia, so the geographical distribution is expanded to the department of Bolívar.

\section{Gnomidolon Thomson, 1864}

\section{Gnomidolon bellus Martins \& Galileo, 2002 \\ (Figs. 1C-1D)}

Material examined: COLOMBIA, Atlántico: Usiacurí (Reserva Campesina La Montaña, $260 \mathrm{~m}, 10^{\circ} 46.0^{\prime} 02.6^{\prime \prime} \mathrm{N}$, $75^{\circ} 00.2^{\prime} 34.0^{\prime \prime} \mathrm{W}$, tropical dry forest), 2 males, 12-13.V.2018, García, K. col., manual capture (MZSP); Bolívar: San Jacinto (Reserva La Flecha, 324 m, 0951.0'12.4"N, 75¹0'41.4"W, tropical dry forest), 1 female, V.2017, Mendoza, I. col., light trap (UARC); Tolima: Armero-Guayabal Mendez (Hda Bremen, 300 m, 0505'317"N, 7445'812"W), 1 male, 17.IX.1995, Fernández, F. col., malaise (MZSP).

Remarks: Gnomidolon bellus was described by Martins \& Galileo (2002) based on two males from Colombia (Tolima). The authors described the integument color as reddish on the prothorax and anterior fifth of elytra. I compared a few specimens from Colombia (from the Caribbean region) with a paratype deposited at the MZSP (Fig. 1C) and noticed that the Caribbean specimens are darker: head, prothorax and anterior half of the elytra black (Fig. 1D), which is considered a chromatic variation as there are no morphological differences between the specimens examined. Currently, this species was only known from the department of Tolima, thus I am registering it for the first time from the department of Atlántico and Bolívar in Colombia.

\section{Gnomidolon franciscoi sp. nov. (Figs. 1E-1H)}

Description: Female: Integument reddish, darker in some areas. Pedicel, antennomere III, and legs black. Antennomere IV-XI light brown, lighter toward apex of antennae. Elytra reddish; each elytron with a black curve band, beginning at middle of anterior fifth, from outer margin toward sutural margin and backing toward outer margin reaching middle of elytron; together both black bands form a " $X$ ", each black band surrounds a pale yellow area; below black band there is a pale yellow area and then a reddish area; elytral apex pale yellow, surrounded by a fine black line anteriorly.

Head: Frons tumid; with distinct sulcus near clypeus; sparsely and coarsely punctate; with irregular wrinkles and short decumbent setae along longitudinal suture, and two long erect setae. Area between antennal tubercles and upper eyes lobes tumid, microsculptured. Vertex irregularly striate; with sparse, coarse punctation and short decumbent setae interspersed with long erect setae. Antennal tubercles elevated, acute at apex, irregularly striate, with sparse and coarse punctation. Longitudinal sulcus only evident in frons and area between antennal tubercles. Submentum with transverse coarse wrinkles and long, erect setae. Genae with coarse punctation and long, decumbent setae. Distance between upper eye lobes 3.5 times width of an upper eye 
lobe. Antennae 2.2 times elytral length, reaching elytral apex at antennomere VIII. Scape cylindrical, with apex projected on outer margin; densely and finely punctate, with a few long, erect setae. Pedicel with long erect setae at apex. Antennomeres III-VII multicarinate, with carinae more evident in III and IV; and with long, erect setae at inner side. Antennal formula (ratio) based on length of antennomere III: scape $=0.74$; pedicel $=0.11$; IV $=0.75$; $\mathrm{V}=0.79 ; \mathrm{VI}=0.72 ; \mathrm{VII}=0.64 ; \mathrm{VIII}=0.56 ; \mathrm{IX}=0.50 ; \mathrm{X}=0.44 ;$ $\mathrm{XI}=0.55$.

Thorax: Prothorax cylindrical, with parallel sides; 1.8 times longer than wide. Surface of pronotum smooth, with a few short, decumbent setae, interspersed with a few long, erect setae. Lateral sides of prothorax with same sculpture as remaining. Prosternum slightly striated on anterior half, smooth on remaining surface; with sparse, short, decumbent setae. Prosternal process pu- bescent; slightly narrowed at middle and expanded toward apex; posterior margin truncate; width at narrowest point about 0.2 times of procoxal cavity width. Mesanespisternum and mesepimeron densely pubescent. Mesoventrite pubescent; tumid toward mesoventral process. Mesoventral process pubescent; emarginated at apex; width at narrowest point about half of mesocoxal cavity width. Metanepisternum densely pubescent. Metaventrite smooth; with sparse short, decumbent setae interspersed with a few long, erect setae; densely pubescent in lateroanterior and lateroposterior margins. Scutellum pubescent, denser at apex; posterior margin rounded. Elytra with dense, coarse punctation on anterior half, sparser and finer toward apex; with long erect setae organized in three longitudinal rows, irregularly aligned toward apex. Apex of elytra truncate, with long outer spine, 0.8 times length of pedicel; inner angle not projected.
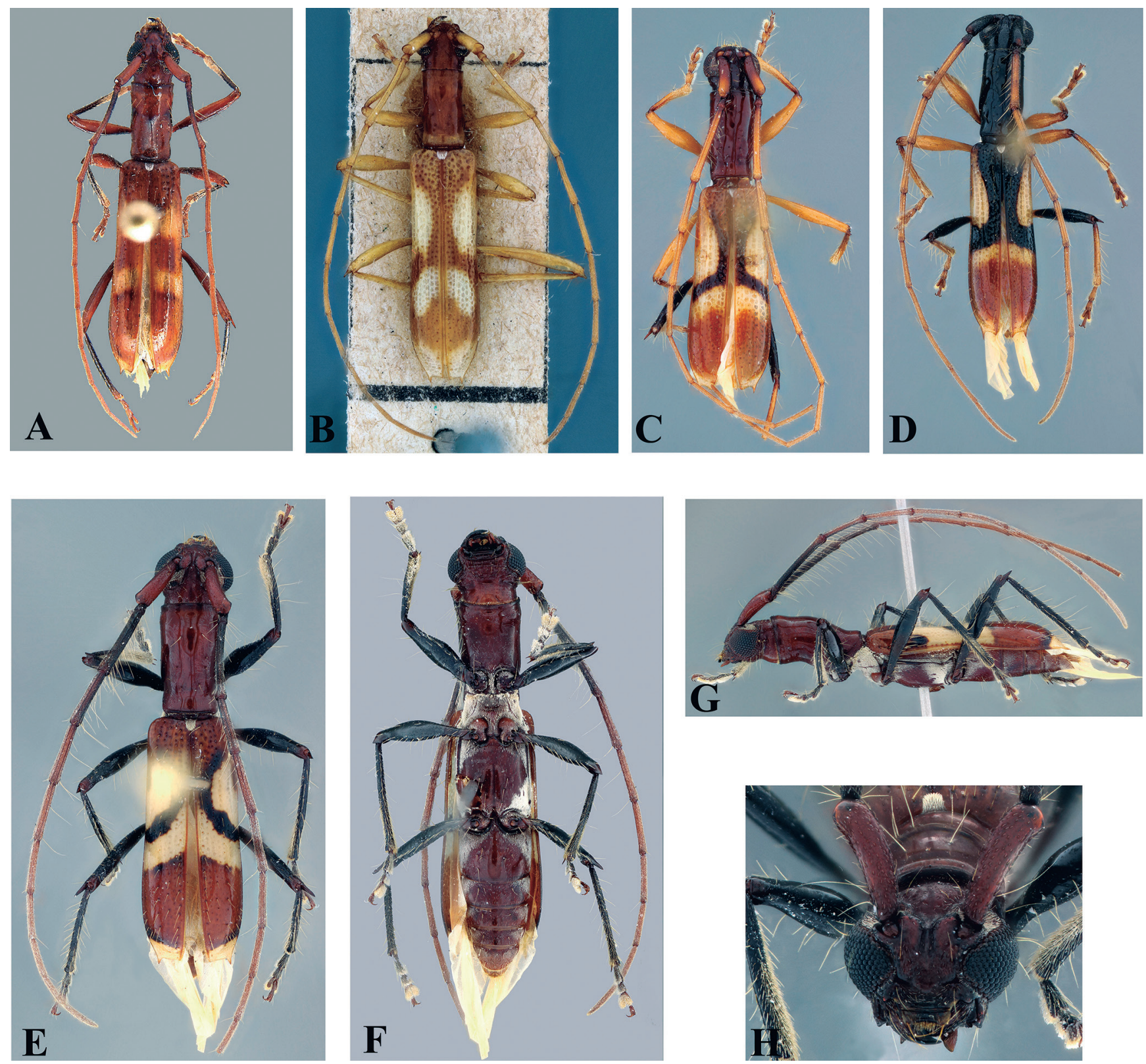

Figure 1. (A-B) Glyptoscapus pallidulus (White, 1855): (A) dorsal view, male; (B) dorsal view female. (C-D) Gnomidolon bellus Martins \& Galileo, 2002: (C) dorsal view, paratype male; (D) dorsal view, male. (E-H) Gnomidolon franciscoi sp. nov., holotype, female: (E) dorsal view; (F) ventral view; (G) lateral view; (H) frontal view. 
Legs: Pro- and mesofemora subfusiform, metafemora cylindrical; with sparse long, erect setae. Mesofemoral apices projected in spicule at outer margin and with a spine at inner margin; metafemoral apices with small spicule at inner margin and long spine at outer margin, 1.9 times length of pedicel. Tibiae carinate (mainly mesoand metatibiae); with sparse long, erect setae, denser toward apex. Metatarsomere I slightly shorter than II-III together.

Abdomen: Ventrites laterally pubescent; with sparse long, erect setae. Ventrite I subequal in length than II-III together. Apex of ventrite $\mathrm{V}$ rounded.

Variability: Some specimens have darker integument, being light brown. Antennae of female shorter. The antennae are lighter in one of the specimens (reddish). The ventral pubescence is sparser in some specimens. The black line that surrounds the apical pale yellow area in the elytra can be lighter or absent.

Measurements (in $\mathbf{~ m m ) : ~ H o l o t y p e , ~ f e m a l e , ~ t o t a l ~ l e n g t h ~}$ (w/ spine): 10.9, prothorax length: 2.9, largest prothoracic width: 1.6, elytral length (w/ spine): 6.7, humeral width: 2.2. Paratypes, $\sigma^{\pi} / q, \mathrm{n}=2 / 1$. Total length ( $\mathrm{w} /$ spine): 10.8-12.2 / 8.4, prothorax length: 2.9-3.4 / 2.3, largest prothoracic width: 1.7-1.9 / 1.1, elytral length (w/ spine): 6.5-7.2 / 5.1, humeral width: 2.1-2.4 / 1.6.

Type material: Holotype female: COLOMBIA, Bolívar: San Jacinto (Reserva La Flecha, 324 m, 09 $51^{\prime} 12.4^{\prime \prime} \mathrm{N}$, $75^{\circ} 10^{\prime} 41.4^{\prime \prime}$ W, tropical dry forest), 15.IV.2018, García, K. col., beating sheet, MPUJ_ENT 0061409 (MPUJ).

Paratypes: PANAMÁ, Bayano: (E. cañitas, 28 km), 1 male, 07.VI.1984, Hovore, F.T. col. (CAS); Cerro azul/Jefé, 1 female, 21.I.1996, Hovore, F.T. col (CAS). COLOMBIA, Atlántico: Usiacurí (Reserva Campesina La Montaña, $260 \mathrm{~m}, 10^{\circ} 46.0^{\prime} 2.6^{\prime \prime} \mathrm{N}, 75^{\circ} 00.2^{\prime} 34.0^{\prime \prime} \mathrm{W}$, tropical dry forest), 1 male, 09.VI.2018, García, K. col., manual capture (UARC); Bolívar: San Jacinto (Reserva La Flecha, 324 m, $09^{\circ} 51^{\prime} 12.4^{\prime \prime} \mathrm{N}, 75^{\circ} 10^{\prime} 41.4^{\prime \prime} \mathrm{W}$, tropical dry forest), X.2015, Mendoza, I. col., manual capture (UARC); Chocó: (PNN los katios, centro administrativo Sautatá, $30 \mathrm{~m}, 07^{\circ} 51^{\prime} \mathrm{N}$, $77^{\circ} 08^{\prime} \mathrm{W}$, forest), 1 female, 20.XI-12.XII.2003, Lopez, P. col., Malaise, IAvH-E-209965 (IAVH).

Etymology: The species epithet is in honor of my friend and colleague Francisco Nascimento (MZSP), for his contribution to the knowledge of Cerambycidae in the Neotropical Region.

Remarks: Gnomidolon franciscoi sp. nov. is similar to G. bellus Martins \& Galileo, 2002 (Fig. 1C-1D), G. biarcuatum (White, 1855), G. musivum (Erichson, 1847) and G. rubricolor Bates, 1870 by the general pattern of elytra color, with an oblique band on each elytron, forming a " $\mathrm{X}$ " when together; the pale yellow area below the oblique band and the elytral apex pale yellow with a long outer spine. Gnomidolon franciscoi sp. nov. differs of G. bellus in having the legs and antennae black; the "X" black band extends reaching the external margin anteriorly; and a black line delimiting anteriorly the pale yellow area of the elytral apex (although this black line can disappear in some specimens). In $G$. bellus the pro- and mesolegs, the metatibiae, and the antennae are yellow; the " $X$ " black band does not extend to the external margin anteriorly; and the black line above the pale yellow area in the elytral apex is absent. Gnomidolon franciscoi sp. nov. differs of G. biarcuatum in having dark femora; the " $X$ " black band reaches the external margin anteriorly; and the anterior region of elytra reddish. Gnomidolon biarcuatum has the pro- and mesofemora yellow and the metafemora black; the " $\mathrm{X}$ " black band does not reach the external margin anteriorly; and the general coloration of elytra is yellowish. Gnomidolon franciscoi sp. nov. differs of G. musivum in having the elytral " $X$ " band black and continuous; the legs and antennae black; and the outer spine of mesofemora projected. In G. musivum the elytral " $X$ " band is pale yellow and discontinuous; the legs and antennae are reddish; and the mesofemora apex is not projected. Gnomidolon franciscoi sp. nov. differs of G. rubricolor in having the " $X$ " black band backing toward the outer margin reaching the middle of the elytron; black femora; and having equal spines in the mesofemora. Gnomidolon rubricolor does not have the "X" black band backing toward the outer margin; the femora are light reddish; and the inner spine of mesofemora is more projected than the outer spine. Gnomidolon franciscoi sp. nov. is also similar to $G$. varians Gounelle, 1909 by having prothorax without microsculpture and longitudinal bands, the elytral apex pale yellow (in some specimens of $G$. varians) with a long outer spine and metafemora concolorous with pro- and mesofemora. Gnomidolon franciscoi sp. nov. differs from G. varians in having reddish integument; scape apex projected at outer margin; a " $X$ " black band on elytra; dark antennae and legs. Gnomidolon varians have yellowish integument; scape subcylindrical; elytra without " $X$ " black band; and antennae and legs yellow.

\section{According to the key to species of Gnomidolon (Martins, 2006), the new species can be inserted as follows (translated and modified):}

26(25) Metafemora with different coloration of pro- and mesofemora ... 27

- Metafemora concolorous with pro- and mesofemora.................... 28

27(26) Light band of apical half of elytra straight; metafemora generally black or dark brown. (Prothorax elongated; size of elytra equal to 2.2-2.4 times the size of prothorax). Peru ........... G. peruvianum Martins, 1960

- Other coloration patterns .............................................................27

27'(27) Smaller size $(8.2-9.0 \mathrm{~mm})$; apical 2/3 of metafemora black; prothorax reddish or black. Colombia (Atlántico, Bolívar, Tolima) ..... G. bellus Martins \& Galileo, 2002

- Greater size (10.6-13.3 mm); metafemora orange, darker on inner face; prothorax black, dark brown or reddish with black band on center of pronotum. Venezuela, Guiana, Guiana Francesa, Peru, Brazil (Amazonas, Pará, Mato Grosso)...G. biarcuatum (White, 1855)

28(26) Elytra mainly yellowish except for dark brown band with variable shape; antennae and legs yellowish. Brazil (Paraíba to Rio Grande 
do Sul, Mato Grosso, Goiás), Paraguay, Argentina, Uruguay.

G. varians Gounelle, 1909

- Basal third of elytra reddish; apical third of elytra reddish except for pale yellow band on apex; antennae and legs reddish-brown or black. Colombia (Atlántico, Bolívar, Chocó)......... G. franciscoi sp. nov.

\section{Gnomidolon hamatum Linsley, 1935}

(Fig. 2)

Redescription: Male: Integument yellow, darker in some areas. Head and prothorax brown. Ventral habitus dark brown. Each elytron with a semicircular dark brown band on anterior half, beginning near base and reaching middle of elytron.

Head: Frons tumid on area close to clypeus; tumid area glabrous surrounded by coarse punctation. Longitudinal sulcus evident on frons and area between antennal tubercles, with dense, coarse punctation and few decumbent setae. Area between antennal tubercles densely, coarsely punctate. Vertex with shallow depression; sparsely and coarsely punctate; with a few long, erect setae. Area behind eye lobes with long erect setae.
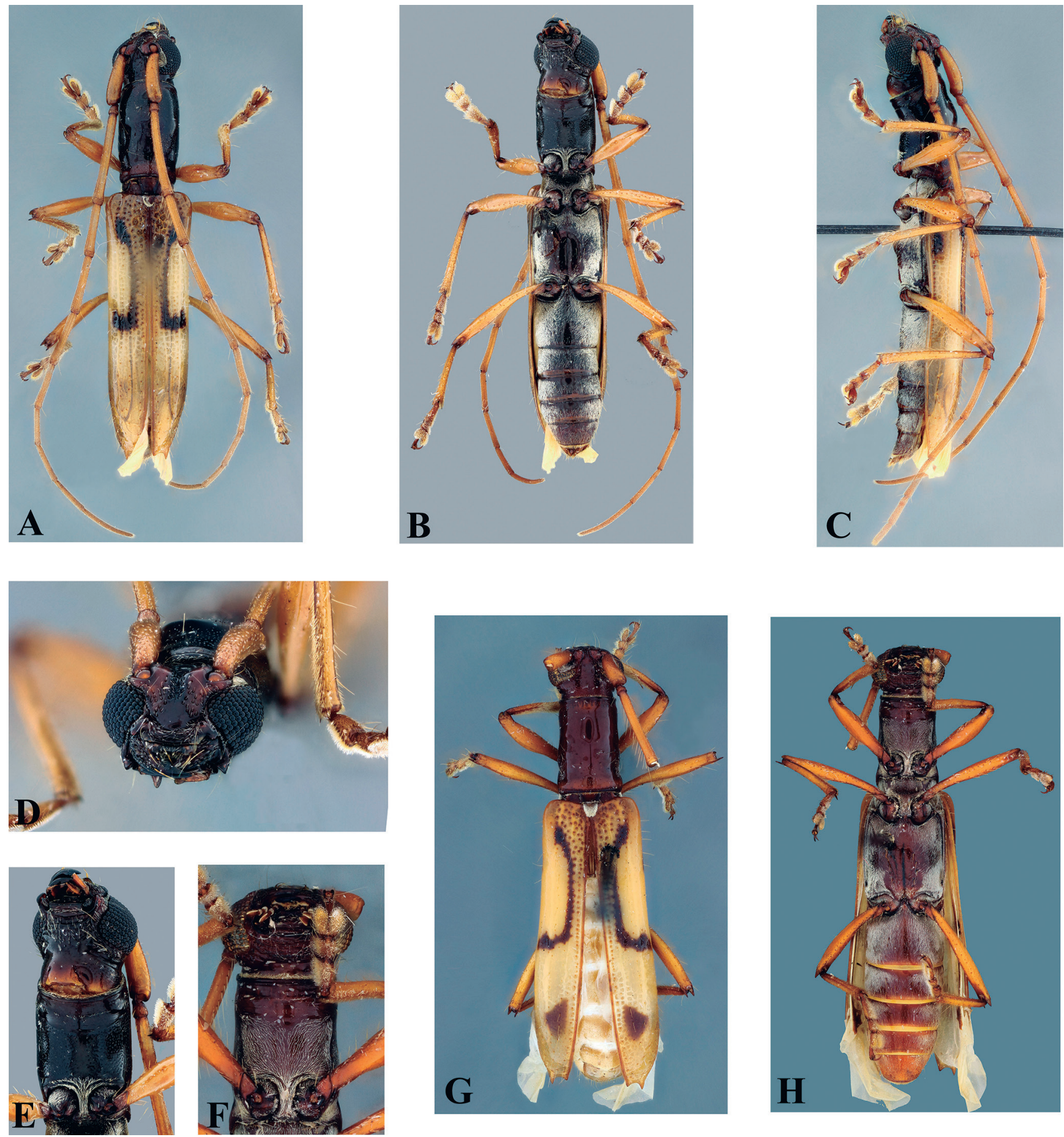

Figure 2. Gnomidolon hamatum Linsley, 1935. (A-E) male: (A) dorsal view; (B) ventral view; (C) lateral view; (D) frontal view; (E) detail of prosternum. (F-H) female: (F) detail of prosternum; $(\mathrm{G})$ dorsal view; $(\mathrm{H})$ ventral view. 
Submentum coarsely striate; with short and long erect setae. Antennal tubercles microsculptured, elevated, rounded at apex. Distance between upper eyes lobes 2.3 times width of upper lobe. Antennae twice elytral length, reaching elytral apex at antennomere IX. Scape cylindrical; scape and pedicel with short decumbent setae. Antennomere III distinctly elongated, 1.7 times length of antennomere IV. Antennomeres IV-X subequal in length, with yellow short decumbent setae; III-IV with long erect setae at inner face, and $\mathrm{V}$-X with long erect setae at apex. Antennomere III-V bicarinate. Antennal formula (ratio) based on length of antennomere III: scape $=0.55$; pedicel $=0.11 ; \mathrm{IV}=0.58 ; \mathrm{V}=0.64 ; \mathrm{VI}=0.66 ; \mathrm{VII}=0.63$; $\mathrm{VIII}=0.57 ; \mathrm{IX}=0.54 ; \mathrm{X}=0.54 ; \mathrm{XI}=0.73$.

Thorax: Prothorax cylindrical, with parallel sides; 1.5 times longer than wide. Pronotal disk with 2 median smooth gibbosities. Surface of pronotum with dense, fine punctation and a few long, erect setae, except for gibbosities. Lateral sides of prothorax with same sculpture as pronotum. Prosternum glabrous on anterior margin, slightly striated with a transversal, fine line of short decumbent setae; remaining area with dense, fine sexual punctation. Prosternal process pubescent and narrow, divergent toward apex, apex truncate, width at narrowest point about 0.2 times of procoxal cavity width. Mesoventrite pubescent, tumid in area close to mesoventral process. Mesoventral process sparsely pubescent, emarginated on apex, width at narrowest point about half of mesocoxal cavity width. Mesanepisternum and mesepimeron densely pubescent. Metaventrite densely pubescent, except centrally with a few short decumbent setae interspersed with long erect setae. Metanepisternum pubescent. Scutellum sparsely pubescent, denser on apex; rounded at apex. Elytra densely and coarsely punctate on anterior half, finer toward apex; with long, erect setae aligned in three longitudinal rows, denser and irregularly aligned toward apex; each elytron with one oblique dark-brown band. Apex emarginated with long spine at outer angle, 0.8 times length of pedicel; and small sutural projection.

Legs: Femora cylindrical (mainly metafemora); with long, erect setae on inner face; apex of mesofemora with short spine at inner side; apex of metafemora with short spine at inner and outer side. Meso- and metatibiae carinate; with sparse long erect setae, denser toward apex. Metatarsomere I subequal in length than II-III together.

Abdomen: Ventrites densely pubescent, with a few long erect setae; ventrite I longer than II-III together; apex of ventrite $\mathrm{V}$ truncate.

Measurements (in $\mathbf{m m}$ ): Male, total length: 12.6, prothorax length: 2.7, largest prothoracic width: 1.9, elytral length: 8.3, humeral width: 2.6.

Material examined: COLOMBIA, Atlántico: Usiacurí (Reserva Campesina La Montaña, 260 m, 1046.0'2.6"N 7500.2'34.0"W, tropical dry forest), 1 male, 12-13.V.2018, García, K. col., white light trap MPUJ_ENT 0064763 (MPUJ).
Remarks: Gnomidolon hamatum was described by Linsley (1935) based on a single female specimen from Panama. Later, Martins (1967) redescribed the female examining the holotype. The species was included in several catalogues, expanding its distribution to Costa Rica (Swift et al., 2010). Herein, the male is described and illustrated for the first time, and sexual dimorphism in the punctation on prosternum is observed (Fig. 2E), as well as differences in the pilosity on prosternum between females and males (Fig. 2F). This sexual dimorphism in the pronotal pilosity is also present in G. guianense, however males of this species present the same punctation as females. The male of $G$. hamatum also differs from the female (Figs. 2F-2H) in lacking the posterior dark brown spot with triangular shape (Fig. 2G). As the material examined is from Colombia, the geographical distribution of the species is expanded to South America.

\section{New geographical records in Hexoplonini}

\section{Glyptoscapus pallidulus (White, 1855)}

Geographical distribution: Colombia (Magdalena), Peru, Bolivia, French Guiana, Brazil (Pará, Rondônia, Goiás, Bahia, Minas Gerais, Espírito Santo, Rio de Janeiro, São Paulo, Paraná), Argentina (Misiones). A new department record is added: Colombia (Bolívar).

Specimens examined: COLOMBIA, Bolívar: San Jacinto (Reserva La Flecha, 324 m, 0951'12.4"N, 75¹0'41.4"W, tropical dry forest), 2 males, 15.IV.2018, García, K. col., Beating sheet (UARC).

\section{Gnomidolon bellus Martins \& Galileo, 2002}

Geographical distribution: Colombia (Tolima). New department records are added: Atlántico and Bolívar (Colombia).

Specimens examined: COLOMBIA, Atlántico: Usiacurí (Reserva Campesina La Montaña, $260 \mathrm{~m}, 10^{\circ} 46.0^{\prime} 2.6^{\prime \prime} \mathrm{N}$, $75^{\circ} 00.2^{\prime} 34.0^{\prime \prime} \mathrm{W}$, tropical dry forest), 2 males, 12-13.V.2018, García, K. col., manual capture (MZSP); Bolívar: San Jacinto (Reserva La Flecha, 324 m, 0951'12.4"N, 75¹0'41.4"W, tropical dry forest), 1 female, V.2017, Mendoza, I. col., light trap (UARC).

\section{Gnomidolon hamatum Linsley, 1935}

Geographical distribution: Colombia (Tolima). New department records are added: Atlántico and Bolívar (Colombia).

Specimens examined: COLOMBIA, Atlántico: Usiacurí (Reserva Campesina La Montaña, $260 \mathrm{~m}, 10^{\circ} 46.0^{\prime} 2.6^{\prime \prime} \mathrm{N}$, $75^{\circ} 00.2^{\prime} 34.0^{\prime \prime} \mathrm{W}$, tropical dry forest), 1 male, 12-13.V.2018, García, K. col., white light trap MPUJ_ENT 0064763 (MPUJ). 


\section{Gnomidolon ornaticolle Martins, 1960}

Geographical distribution: Costa Rica, Panama, Brazil (Minas Gerais, Espírito Santo, Rio de Janeiro, São Paulo, Paraná, Santa Catarina, Rio Grande do Sul), Paraguay, Argentina (Misiones). A new country record is added: Colombia (Bolívar).

Specimens examined: COLOMBIA, Bolivar: San Jacinto (Reserva La Flecha, $324 \mathrm{~m}, 09^{\circ} 51^{\prime} 12.4^{\prime \prime} \mathrm{N}, 75^{\circ} 10^{\prime} 41.4^{\prime \prime} \mathrm{W}$, tropical dry forest), 1 female, 16.IV.2018, García, K. col., UV light trap (UARC).

\section{AKNOWLEDGMENTS}

I am grateful to Juan Pablo Botero (MZSP) for his help in the development of this article, as well as for the photographs of the specimens; to the members of "NEOPTERA" team, especially to Neis Martínez, Jeniffer Meriño and José Sarmiento for their help collecting specimens used in this study; to Antonio Santos-Silva (MZSP) and Francisco Nascimento (MZSP) for their help in the identification of some specimens; to Sônia Casari for her kind help and support during my stay in the MZSP; and to the curators of the collections visited for the loan of specimens.

\section{REFERENCES}

Bezark, L.G. 2019. A photographic Catalog of the Cerambycidae of the New World. Available at: https://apps2.cdfa.ca.gov/publicApps/plant/ bycidDB/wsearch.asp?w=n-. Access in: 03/2019.

Botero, J.P. 2018. La familia Cerambycidae (Coleoptera: Chrysomeloidea) en Colombia. In: Deloya, C. \& Gasca, H. (Eds.). Escarabajos del neotropico (Insecta: Coleoptera). Ciudad de México, Sy G Editores. p. 153-169.
Lacordaire, J.T. 1868. Histoire Naturelle des Insectes. Genera des Coléoptères, ou exposé méthodique et critique de tous les genres proposés jusqu'ici dans cet ordre d'insectes. Paris, Librairie Encyclopédique de Roret. v. 8, 552p.

Linsley, E.G. 1935. Notes and descriptions of new or little known Neotropical Ibidionini (Col. Cerambycidae). Revista de Entomologia, 5(4): 479-486.

Martínez, C. 2000. Escarabajos longicornios (Coleoptera: Cerambycidae) de Colombia. Biota Colombiana, 1(1): 76-105.

Martins, U.R. 1967. Monografia da tribo Ibidionini (Coleoptera, Cerambycidae). Parte I. Arquivos de Zoologia, 16(1): 1-320.

Martins, U.R. 2006. Cerambycidae sul-americanos (Coleoptera). Taxonomia Volume 8. Subfamília Cerambycinae Phoracanthini Newman, 1840 Hexoplonini trib. nov. São Paulo, Sociedade Brasileira de Entomologia. 234p.

Martins, U. \& Galileo, M.H. 2002. Cerambycidae (Coleoptera) da Colômbia. II. Ibidionini (Cerambycinae). Iheringia, Serie Zoologia, 92(4): 11-18.

Monné, M.A. 2018. Catalogue of the Cerambycidae (Coleoptera) of the Neotropical region. Part I. Subfamily Cerambycinae. Available at: http:// cerambyxcat.com. Access in: 03/2019.

Nascimento, F.E. \& Santos-Silva, A. 2018. New species and synonymies in Hexoplonini Martins, 2006 (Coleoptera, Cerambycidae), with notes and new records on Cerambycinae Latreille, 1802. Papéis Avulsos de Zoologia, 58(e20185836): 1-8. Disponível em: http://www.revistas.usp.br/paz/ article/view/144979. Acesso em: 25/07/2019.

Swift, I.P.; Bezark, L.G.; Nearns, E.H.; Solís, A. \& Hovore, F.T. 2010. Checklist of the Cerambycidae (Coleoptera) of Costa Rica. Insecta Mundi, 0131: 1-68.

Tavakilian, G. \& Chevillotte, H. 2018. Titan: base de données internationales sur les Cerambycidae ou Longicornes. Version 3.0. Available at: http://titan. gbif.fr. Access in: 03/2019.

Thomson, J. 1864. Systema Cerambycidarum ou exposé de tous les genres compris dans la famille des Cérambycides et familles limitrophes. Mémoires de la Société Royale des Sciences de Liège, 19: 1-540.

White, A. 1855. Catalogue of the coleopterous insects in the collection of the British Museum, Longicornia II. London, Taylor and Francis. 237p. 